\title{
GMR
}

\section{Genetic potential of common bean progenies obtained by different breeding methods evaluated in various environments}

\author{
V.A. Pontes Júnior ${ }^{1}$, P.G.S. Melo ${ }^{1}$, H.S. Pereira ${ }^{2}$ and L.C. Melo ${ }^{2}$ \\ ${ }^{1}$ Escola de Agronomia, Universidade Federal de Goiás, Goiânia, GO, Brasil \\ ${ }^{2}$ Embrapa Arroz e Feijão, Santo Antônio de Goiás, GO, Brasil \\ Corresponding author: L.C. Melo \\ E-mail: leonardo.melo@embrapa.br
}

Genet. Mol. Res. 15 (3): gmr.15038622

Received March 21, 2016

Accepted April 25, 2016

Published September 2, 2016

DOI http://dx.doi.org/10.4238/gmr.15038622

Copyright (C) 2016 The Authors. This is an open-access article distributed under the terms of the Creative Commons Attribution ShareAlike (CC BY-SA) 4.0 License

\begin{abstract}
Grain yield is strongly influenced by the environment, has polygenic and complex inheritance, and is a key trait in the selection and recommendation of cultivars. Breeding programs should efficiently explore the genetic variability resulting from crosses by selecting the most appropriate method for breeding in segregating populations. The goal of this study was to evaluate and compare the genetic potential of common bean progenies of carioca grain for grain yield, obtained by different breeding methods and evaluated in different environments. Progenies originating from crosses between lines and CNFC 7812 and CNFC 7829 were replanted up to the $\mathrm{F}_{7}$ generation using three breeding methods in segregating populations: population (bulk), bulk within $\mathrm{F}_{2}$ progenies, and single-seed descent (SSD). Fifteen $\mathrm{F}_{8}$ progenies per method, two controls (BRS Estilo and Perola), and the parents were evaluated in a $7 \times 7$ simple lattice design, with plots of two 4-m rows. The tests were conducted in 10 environments in four States of Brazil
\end{abstract}


and in three growing seasons in 2009 and 2010. Genetic parameters including genetic variance, heritability, variance of interaction, and expected selection gain were estimated. Genetic variability among progenies and the effect of progeny-environment interactions were determined for the three methods. The breeding methods differed significantly due to the effects of sampling procedures on the progenies and due to natural selection, which mainly affected the bulk method. The SSD and bulk methods provided populations with better estimates of genetic parameters and more stable progenies that were less affected by interaction with the environment.

Key words: Phaseolus vulgaris L.; Sampling effect; Natural selection; Genotype-environment interaction

\section{INTRODUCTION}

Breeding programs of common bean (Phaseolus vulgaris L.) performed by public research institutions in Brazil have supplied the market with new cultivars. These cultivars combine desirable traits such as disease resistance, early maturity, better adaptation to mechanical harvesting, and higher yield potential, resulting in an increase in crop yield from $958 \mathrm{~kg} / \mathrm{ha}$ in 2002 to $1353 \mathrm{~kg} / \mathrm{ha}$ in 2013 (Feijão, 2015).

Grain yield is widely studied by breeders and is decisive for the selection and recommendation of cultivars. This character is rather complex, has polygenic inheritance, and is greatly influenced by environmental variations (Pereira et al., 2012; Torga et al., 2013). As a result, sufficient genetic variability must be available to successfully develop higher-yielding cultivars in breeding programs, and efficient strategies should exist to detect differences between elite genotypes, allowing genetic gains. The factors that most affect the efficiency of this process are the existence of genotype-environment (GE) interactions and the choice of an adequate breeding method for segregating populations, following careful identification of the parents (Raposo et al., 2000; Pontes Júnior et al., 2015).

Common bean is grown in almost all states of Brazil and in more than one growing season peryear in most of these, in several cultivation systems, and under different environmental conditions. The effect of the GE interaction on common bean grain yield is pronounced and has been previously described (Carbonell et al., 2004; Melo et al., 2007; Pereira et al., 2009, 2010, 2012; Torga et al., 2013). Therefore, it is important to perform tests in representative cultivation environments in order to determine the effect of the GE interaction on estimates of genetic parameters, both in the process of breeding segregating populations and when selecting superior lines. These evaluations are needed to determine the nature of the genes involved in the inheritance of the trait under study and to guide the selection of the most efficient breeding methods, thus aiding breeders in decision making (Ramalho et al., 2001). Few studies have addressed these issues, and this may be associated with the high cost of selecting the same population over several generations by different breeding methods in breeding programs, and the difficulties of carrying out consistent tests in various environments.

Breeders also agree that the selection of segregating populations stage of process of breeding segregating populations is one of the most laborious, costly, and critical phases in

Genetics and Molecular Research 15 (3): gmr.15038622 
breeding programs of autogamous species. Many methods (bulk, bulk within $\mathrm{F}_{2}$, pedigree, and single-seed descent (SSD) have been simplified and optimized for use to reduce the costs of cultivar development in the breeding of these species (Vales et al., 2009). Breeding methods used to develop some common bean cultivars in public institution programs were assessed by Moreira et al. (2010), who reported good performance of the pedigree, bulk and single-pod descent methods. The bulk within $\mathrm{F}_{2}$ and $\mathrm{F}_{3}$ methods are also often used in common bean breeding programs in Brazil (Ramalho et al., 2012).

Methods should be selected based on the objective of the breeding program, the available (financial and human) resources, the target trait, the need to maintain variability over generations, the potential to develop better progenies, and the effects of natural selection and sampling. The methods used for selection of grain yield in segregating populations have been compared in various crops such as soybean (Destro et al., 2003; Miladinović et al., 2011; Funada et al., 2013), common bean (Raposo et al., 2000; Costa et al., 2002), cowpea (Mehta and Zaveri, 2000), chickpea (Meena and Kumar, 2012), barley (Lalić et al., 2003), sesame (Vinayan and Govindarasu, 2010), cauliflower (Chigeza et al., 2013), and rice (Fahim et al., 1998; Ntanos and Roupakias, 2001; Kanbar et al., 2011). Most of these studies showed significant differences between the methods used for developing superior progenies or lines. However, with the establishment of cultivars with increasingly high-yields, the differences detected in the breeding programs are small and require more efficient strategies. According to Faria et al. (2013), over a period of 22 years, the Embrapa breeding program of carioca common bean resulted in yield gains of around $0.72 \%$ p.a. $(17.3 \mathrm{~kg} / \mathrm{ha})$, similar to the gain reported by Matos et al. (2007). This reinforces the need to continuously evaluate and seek more efficient ways to ensure continuous progress in common bean breeding.

In view of the wide scope of the common bean breeding program of Embrapa Arroz e Feijão, and the need to define better selection strategies for segregating populations, the objective of this study was to compare the genetic potential for grain yield of common bean progenies with carioca grain, obtained by three breeding methods and evaluated in different environments.

\section{MATERIAL AND METHODS}

Common bean progenies were obtained from a cross between the elite breeding lines, CNFC 7812 and CNFC 7829 of the Carioca commercial group developed by the breeding program of Embrapa Arroz e Feijão. The populations were subjected to three breeding methods: the population or bulk (1000 plants per generation up to $\mathrm{F}_{5}$, with random selection of 100 plants in the last generation); the modified population or bulk within $\mathrm{F}_{2}$ families (100 families per generation up to $\mathrm{F}_{5}$ ); and progeny of a single seed or SSD (100 seeds per generation up to $\mathrm{F}_{5}$ ). The selection of these segregating populations was performed as described by Ramalho et al. (2001), and adapted by Ramalho et al. (2012). From the $\mathrm{F}_{5}$ generation, 64 progenies were randomly sampled for each method, with multiplication in the $\mathrm{F}_{6}$ and $\mathrm{F}_{7}$ generations. Fifteen randomly selected progenies per method were evaluated, which were identified as $\mathrm{F}_{5: 8}$ for bulk and SSD, and $\mathrm{F}_{2: 8}$ for bulk within $\mathrm{F}_{2}$. The experimental design was a 7 x 7 simple lattice, with plots of two 4-m rows, spaced $0.5 \mathrm{~m}$ apart, with 15 seeds per meter. Two controls (BRS Estilo and Perola) were used as well as the two parents of the study population. The field trials were evaluated in different locations, months, and years of planting in the states of Paraná,

Genetics and Molecular Research 15 (3): gmr.15038622 
Minas Gerais, Goiás, and Pernambuco. The tests were installed in the municipalities of Ponta Grossa-PR $\left(25^{\circ} 13^{\prime} \mathrm{S}, 50^{\circ} 01^{\prime} \mathrm{W}, 880 \mathrm{~m}\right)$, Lavras-MG $\left(21^{\circ} 22^{\prime \prime} \mathrm{S}, 4^{\circ} 97^{\prime} \mathrm{W}, 960 \mathrm{~m}\right)$, Sete LagoasMG (19 $\left.47^{\prime} \mathrm{S}, 44^{\circ} 25^{\prime} \mathrm{W}, 732 \mathrm{~m}\right)$, Anápolis-GO (16 $\left.37^{\circ} \mathrm{S}, 48^{\circ} 94^{\prime} \mathrm{W}, 1017 \mathrm{~m}\right)$, Santo Antônio de Goiás-GO (16 $\left.56^{\circ} \mathrm{S}, 49^{\circ} 30^{\prime} \mathrm{W}, 741 \mathrm{~m}\right)$, and Petrolina-PE $\left(9^{\circ} 15^{\prime} \mathrm{S}, 40^{\circ} 37^{\prime} \mathrm{W}, 366 \mathrm{~m}\right)$.

Individual variance for grain yield of the progenies was analyzed in the 10 environments. The variance components and genetic and phenotypic parameters were estimated from the mathematical mean square expectations (Vencovsky and Barriga, 1992).

The homogeneity of variance between experiments was investigated. The mathematical model for combined analysis considered the environments as fixed and the progenies as random (Vencovsky and Barriga, 1992). The progeny effect was partitioned in progenies for each method, and the variance components and their estimates of genetic and phenotypic parameters were obtained. The error associated with estimates of mean heritability of the progenies obtained by the breeding methods was determined as described by Vello and Vencovsky (1974). The expected gain from selection was estimated as the percentage of the five most productive progenies per breeding method.

The ratio between estimates of the variance of GE interaction, and genetic variance for each breeding method of segregating populations was calculated as follows:

$$
R_{i}=\left(\frac{\bar{\sigma}_{g x a_{i}}^{2}}{\hat{\sigma}_{g i}^{2}}\right) * 100
$$

where: $R i$ is the ratio of the interaction of the $i^{\text {th }} \operatorname{method}(i=1,2,3) ; \hat{\sigma}_{g x a_{i}}^{2}$ is the variance of the GE interaction of the $i^{\text {th }}$ method $(i=1,2,3)$; and $\hat{\sigma}_{g i}^{2}$ is the variance of the $i^{\text {th }}$ method $(i=$ $1,2,3)$.

Thereafter, the ratio was calculated as a percentage between the interaction for each method and the sum of the ratios of all methods:

$$
P_{i}=\left(\frac{R_{i}}{R_{1}+R_{2}+R_{3}}\right) * 100
$$

where: $P_{i}$ is the ratio of the interaction of the $i^{\text {th }}$ method $(i=1,2,3)$; and $R_{i}$ is the ratio of the interaction of the $i^{\text {th }}$ method $(i=1,2,3)$.

To compare the methods of selecting segregating populations based on mean grain yield, $10 \%$ of the evaluated progenies were selected. In this way, the number of progenies per method among the five best $\left(P_{5+}\right)$ and five worst $\left(P_{5}\right)$ in the mean of all evaluations was determined. The number of superior progenies over the mean of the parents for each method was also obtained. To compare the mean progeny performance, the ranking in descending order for grain yield was used and the sum of total rankings (STR) was calculated for each method, so that the method with the lowest (STR) was considered the most promising to breed superior progenies.

\section{RESULTS AND DISCUSSION}

Individual analyses of the 10 test environments showed significant differences between

Genetics and Molecular Research 15 (3): gmr.15038622 
genotypes $(\mathrm{P}<0.05)$ in $80 \%$ of the tests, indicating variability among progenies, parents, and controls (Table 1). Values of the experimental variation coefficient were all below $23 \%$ and lower than the maximum acceptable value for the release of new common bean cultivars (25\%), indicating good experimental precision (Brasil, 2006).

Table 1. Individual analyses of variance for grain yield and estimates of genetic and phenotypic parameters evaluated in common bean progenies in 10 environments.

\begin{tabular}{l|l|c|c|c|c|c|c|c|c|c|c}
\hline Environment & $\begin{array}{l}\text { Month/year of } \\
\text { planting }\end{array}$ & $M S_{\text {Error }}$ & $M S_{\text {Treat }}$ & $\mathrm{P}$ value & $\begin{array}{c}\text { Overall } \\
\text { mean }\end{array}$ & $\begin{array}{c}\text { Parental } \\
\text { mean }\end{array}$ & $\hat{\sigma}_{g}^{2}$ & $\hat{\sigma}_{f}^{2}$ & $\hat{h}^{2}(\%)$ & $C V_{g}(\%)$ & $C V_{e}(\%)$ \\
\hline 1. Anápolis-GO & December/2009 & 237,074 & 347,493 & 0.0659 & 2902 & 2925 & - & - & - & - & - \\
\hline 2. SAG & June/2010 & 68,326 & 110,599 & 0.0289 & 2166 & 2349 & 14,091 & 36,866 & 38.22 & 5.48 & 12.07 \\
\hline 3. SAG & February/2010 & 49,053 & 229,326 & 0.0000 & 994 & 1158 & 60,091 & 76,442 & 78.60 & 24.66 & 22.28 \\
\hline 4. SAG & December/2010 & 123,939 & 228,334 & 0.0081 & 2433 & 2428 & 34,798 & 76,111 & 45.72 & 7.67 & 14.47 \\
\hline 5. Ponta Grossa-PR & November/2009 & 146,591 & 319,208 & 0.0011 & 2099 & 2049 & 57,539 & 106,403 & 54.07 & 11.43 & 18.24 \\
\hline 6. Ponta Grossa-PR & January/2010 & 60,213 & 129,162 & 0.0013 & 2207 & 2226 & 22,983 & 43,054 & 53.38 & 6.87 & 11.12 \\
\hline 7. Ponta Grossa-PR & November/2010 & 249,488 & 332,536 & 0.1283 & 3054 & 2932 & - & - & - & - & - \\
\hline 8. Lavras-MG & February/2010 & 272,226 & 600,628 & 0.0009 & 3523 & 3998 & 109,467 & 200,209 & 54.67 & 9.39 & 14.81 \\
\hline 9. Sete Lagoas-MG & February/2010 & 198,354 & 545,157 & 0.0000 & 2850 & 3457 & 115,601 & 181,719 & 63.61 & 11.93 & 15.63 \\
\hline 10. Petrolina-PE & April/2010 & 61,740 & 143,175 & 0.0005 & 1788 & 2043 & 27,145 & 47,725 & 56.88 & 9.21 & 13.90 \\
\hline
\end{tabular}

$\mathrm{SAG}=$ Santo Antonio de Goiás GO; $M S_{\text {Error }}=$ mean square error; $M S_{\text {Treat }}=$ mean square treatment; $\hat{\sigma}_{g}^{2}=$ genetic variance; $\hat{\sigma}_{g}^{2}=$ phenotypic variance; $\hat{h}^{2}=$ heritability; $C V_{g}=$ genetic variation coefficient; $C V_{e}=$ coefficient of experimental variation.

The mean grain yield in the environments varied from 994 to $3523 \mathrm{~kg} / \mathrm{ha}$, which is $354 \%$ higher than the grain yield in the environment with the highest mean compared to that with the lowest mean, indicating that environmental variation exists (Table 1). This difference was also found between the means of the parents, with about $71 \%$ superiority between the extreme values. In addition, in half of the environments the mean of the parents was lower than that of the overall mean. Geographic data of the test locations, revealed marked variations in altitude (366-1017 m), latitude $\left(9^{\circ} 15^{\prime} \mathrm{S}\right.$ to $\left.25^{\circ} 13^{\prime} \mathrm{S}\right)$, and longitude $\left(40^{\circ} 37^{\prime} \mathrm{W}\right.$ to $\left.50^{\circ} 01^{\prime} \mathrm{W}\right)$, which may explain the differentiated response of genotypes in the studied environments.

Heritability $\left(\hat{h}^{2}\right)$, which is an estimate of the proportion of the total variation due to genetic factors, ranged from 38.22 to $78.60 \%$, i.e., medium-to-high, indicating the possibility of gains with selection for grain yield (Table 1). The genetic coefficient of variation $\left(\mathrm{CV}_{g}\right)$ indicates the proportion of genetic variability among progenies in relation to the population mean, which facilitates comparison of the variability of the study trait (Ribeiro et al., 2009). The $C V_{g}$ of the populations assessed in 10 environments ranged from 5.48 to $24.66 \%$ (Table 1). This interval includes the values reported by Raposo et al. (2000) $(7.33 \%)$ and Ribeiro et al. (2009) (16.05\%). The present study differs from those studies in one relevant aspect; more environments were assessed and the populations were obtained by different breeding methods, which enables greater accuracy and consistency in obtaining estimates of genetic and phenotypic parameters.

In the combined analysis, most of the tested effects were significant $(\mathrm{P}<0.05)$, except for the effect of controls, parents, and the interactions: controls-environments, parentsenvironments, and methods-environments (Table 2). Variability among progenies and GE interaction was detected for each method, and the estimates varied greatly between methods (Table 3). Another notable and significant difference was between the breeding methods. These results illustrate the challenge of complexity in common bean breeding programs targeting grain yield and the importance of undertaking studies to identify the most efficient breeding method in segregating populations for this trait, with a view to increase selection gains.

Genetics and Molecular Research 15 (3): gmr.15038622 
Table 2. Combined analyses of variance for grain yield $(\mathrm{kg} / \mathrm{ha})$ of $\mathrm{F}_{8}$ progenies obtained by three breeding methods, assessed in 10 environments.

\begin{tabular}{|c|c|c|c|c|}
\hline Source of variation & Degrees of freedom & Sum of squares & Mean square & P value \\
\hline Environments (E) & 10 & 72.5980 & 7.2598 & 0.0000 \\
\hline Adjusted Treatments (T) & 48 & 24.3036 & 0.5063 & 0.0000 \\
\hline Bulk within $\mathrm{F}_{2}\left(\mathrm{~F}_{2: 8}\right)$ & (14) & 4.5819 & 0.3273 & 0.0000 \\
\hline Bulk-population $\left(\mathrm{F}_{5: 8}\right)$ & (14) & 8.9771 & 0.6412 & 0.0000 \\
\hline $\operatorname{SSD}\left(\mathrm{F}_{5: 8}\right)$ & (14) & 3.8731 & 0.2766 & 0.0000 \\
\hline Checks (Chk.) & (1) & 2.9390 & 2.9390 & 0.0000 \\
\hline Parents (P) & (1) & 0.2116 & 0.2116 & 0.1330 \\
\hline Methods (M) & (2) & 0.8138 & 0.4069 & 0.0140 \\
\hline Chk. $v s \mathrm{P} v s \mathrm{M}$ & (2) & 2.9070 & 1.4535 & 0.0000 \\
\hline TxE & 480 & 128.4480 & 0.2676 & 0.0000 \\
\hline Bulk within $\mathrm{F}_{2}\left(\mathrm{~F}_{2: 8}\right) \times \mathrm{E}$ & (140) & 32.9625 & 0.2355 & 0.0000 \\
\hline Bulk-population $\left(\mathrm{F}_{5: 8}\right) \times \mathrm{E}$ & (140) & 46.3336 & 0.3310 & 0.0000 \\
\hline $\operatorname{SSD}\left(F_{5: 8}\right) \times E$ & (140) & 33.7049 & 0.2408 & 0.0000 \\
\hline Chk. $x \mathrm{E}$ & (10) & 3.2484 & 0.3248 & 0.0000 \\
\hline $\mathrm{P} \times \mathrm{E}$ & (10) & 0.8150 & 0.0815 & 0.5600 \\
\hline $\mathrm{M} \times \mathrm{E}$ & (20) & 4.1259 & 0.2063 & 0.0000 \\
\hline Chk. vs $\mathrm{P} v s \mathrm{M} \times \mathrm{E}$ & (20) & 7.2578 & 0.3629 & 0.0000 \\
\hline Effective mean error & 396 & 37.0260 & 0.0935 & - \\
\hline Mean (\%) & 4.85 & - & - & - \\
\hline Lattice relative efficiency (\%) & 106 & - & - & - \\
\hline
\end{tabular}

Table 3. Estimates of means, genetic and phenotypic parameters for grain yield $(\mathrm{kg} / \mathrm{ha})$ of common bean in $\mathrm{F}_{8}$ progenies for three breeding methods evaluated in 10 environments.

\begin{tabular}{l|c|c|c|c}
\hline Methods & Bulk within $\mathrm{F}_{2}$ & Bulk-population & SSD & Mean \\
\hline$\hat{\sigma}_{g_{i}}^{2}$ & 4,260 & 13,924 & 8,292 & 11,387 \\
\hline$\hat{\sigma}_{f_{i}}^{2}$ & 9,150 & 18,814 & 13,182 & 16,277 \\
\hline$\hat{\sigma}_{g x a_{i}}^{2}$ & 35,597 & 11,485 & 11,203 & 39,234 \\
\hline$\hat{h}_{m_{i}}^{2}$ & 46.56 & 74.01 & 62.90 & 69.96 \\
\hline$S\left(h_{m}^{2}\right)_{i}$ & \pm 20.38 & \pm 9.91 & \pm 14.15 & \pm 6.32 \\
\hline$C V_{g}(\%)$ & 2.73 & 5.06 & 3.72 & 4.47 \\
\hline$C V_{e}(\%)$ & 16.04 & 16.42 & 15.67 & 16.04 \\
\hline$R_{i}(\%)$ & 836 & 82 & 135 & 345 \\
\hline$P_{i}(\%)$ & 79.39 & 7.79 & 12.82 & - \\
\hline Mean & $2388^{\mathrm{a}}$ & $2332^{\mathrm{b}}$ & $2445^{\mathrm{c}}$ & 2388 \\
\hline Mean of five selected progenies & 2484 & 2472 & 2561 & - \\
\hline$S G_{i}(\%)$ & 1.86 & 4.45 & 2.97 & - \\
\hline$\hat{\sigma}^{2}$ & & & & \\
\hline
\end{tabular}

$\hat{\sigma}_{g_{i}}^{2}=$ Genetic variance; $\hat{\sigma}_{g_{i}}^{2}=$ phenotypic variance; $\hat{\sigma}_{g x a_{i}}^{2}=$ variance of genotype-environment interaction; $\hat{h}_{m_{i}}^{2}$ = heritability mean; $S\left(h_{m}^{2}\right)_{i}$ = error associated with heritability estimate; $C V_{g}(\%)=$ genetic variation coefficient; $C V_{e}(\%)=$ coefficient of experimental variation; $R_{i}(\%)=$ interaction rate; $P_{i}(\%)=$ proportion of interaction; $S G_{i}(\%)$ $=$ percentage of selection gain; $\mathrm{SSD}=$ single-seed descent. Means followed by different letters are significantly different by the Scott-Knott means grouping test at $5 \%$.

For the bulk and SSD methods, at the $\mathrm{F}_{5}$ generation, $187.5 \%$ of the additive genetic variance $\left(\hat{\sigma}_{a}^{2}\right)$ is released. For bulk within $\mathrm{F}_{2}$, the variability between progenies is independent of the generation at which selection was applied, since the variability remains the same as that observed between $\mathrm{F}_{2}$ plants, i.e., $100 \% \hat{\sigma}_{\tilde{a}}^{2}$ (Raposo et al., 2000). Conversely, genetic 
variance within families is higher in the bulk breeding method in $\mathrm{F}_{2}$ than in the bulk and SSD methods. This difference was not estimated in the present study, but is expected to decrease in later generations. Therefore, maintaining genetic variability up to the point of testing in experiments with replications is crucial for selection of the populations. Regarding the variability between progenies, those obtained by the bulk and SSD methods had the highest estimates for genetic variance and heritability. Comparing these two methods, the estimates of $\hat{\sigma}_{g i}^{2}, \hat{\sigma}_{f i}^{2}, \hat{h}_{m i}^{2}$, and $C V_{g}$ were all highest in the bulk method.

The mean heritability $\left(\hat{h}_{m i}^{2}\right)$ was $69.96 \%$, and the highest estimate corresponded to the bulk method $(74.01 \%)$, followed by SSD $(62.90 \%)$, and bulk in $\mathrm{F}_{2}(46.56 \%)$, which is consistent with the magnitude of genetic variation of the estimates obtained by each method (Table 3). These estimates (particularly the first two) were medium-to-high for this trait. The estimate of the error associated with $\hat{h}_{m i}^{2}$ was lower for the bulk method $( \pm 9.91)$, followed by SSD $( \pm 14.15)$, and bulk in $F_{2}( \pm 20.38)$. It is possible that these errors are associated with the presence of GE interactions, which, in this case, were higher for the bulk in the $\mathrm{F}_{2}$ method. The $C V_{g}$ should be used together with $\mathrm{h}^{2}$ to compare the genetic variability among progenies derived from different breeding methods. For this estimate, the progenies originated by the bulk and SSD methods were also high.

Since the expected selection gain is a function of heritability in the generation of progeny testing (Ramalho et al., 2001), the methods with the highest estimates are also those with the highest selection gain. The selection gain was highest in the bulk method (4.45\%), followed by SSD (2.97\%), and bulk within $\mathrm{F}_{2}(1.86 \%)$ methods (Table 3). Silva et al. (2013) obtained higher genetic gains, but with the same ratio among methods. These authors worked with the same population, and evaluated the fiber content using a higher number of $F_{7}$ progenies, which were only tested at two locations.

One factor that limits the work of breeders is the existence of GE interactions. The inheritance of grain yield is polygenic and is strongly influenced by the environment, and heritability of this trait is low (Corte et al., 2002). Several studies on common bean have shown that the GE interaction has a marked effect on the grain yield of this crop (Carbonell et al., 2004; Melo et al., 2007; Pereira et al., 2009, 2010, 2012; Torga et al., 2013).

Considering all progenies, regardless of the method used, the variance of the GE interaction $\left(\hat{\sigma}_{g x e_{i}}^{2}\right)$ was $345 \%\left(R_{i}\right)$ of the estimate of genetic variance $\left(\hat{\sigma}_{g i}^{2}\right)$, i.e., almost five times higher than that reported by Raposo et al. (2000) for common bean. For bulk-derived progenies, this estimate was $82 \%$, for SSD it was $135 \%$, and for bulk within $\mathrm{F}_{2}$ progenies it was $836 \%$. For the bulk-derived progenies, the proportion of interaction $\left(P_{i}\right)$ was $7.79 \%$, followed by SSD (12.82\%), and bulk within $\mathrm{F}_{2}(79.39 \%)$ (Table 3). For the latter, the proportion of the variance of interaction $\left(P_{i}\right)$ was more than 10-fold higher than that with the bulk method, and more than six-fold higher than with SSD. These differences can be explained by the magnitude of genetic variance among progenies, which was higher for the bulk and SSD methods.

During breeding, several factors can affect the efficiency of methods, including the GE interaction. This was taken into consideration in the present study, since when the progenies were evaluated in different environments, a lower environmental influence was observed by the bulk and SSD methods. This is a positive factor for the development of superior and stable lines that are adapted to environmental variations. This is essential for the success of breeding programs that seek cultivars with wide adaptation, as in the case of common bean (Del Peloso and Melo, 2005).

Genetics and Molecular Research 15 (3): gmr.15038622 
When $10 \%$ of the best progenies were selected, the SSD method resulted in the highest percentage of progenies $(80 \%)$ among the five best progenies, followed by the bulk method $(20 \%)$ (Table 4). Among the five worst progenies, the bulk method had the highest percentage (60\%), followed by the bulk in $\mathrm{F}_{2}$ and SSD methods, which both had $20 \%$. Six progenies (five SSD and one bulk) were found to exceed the mean of the parents; however, none of the progenies had a higher mean than the higher-yielding parent (CNFC 7812). Progenies with better performance than the parent CNFC 7829 were identified, as well as progenies with lower means than both parents, indicating the presence of transgressive segregation, resulting in plants with yield values beyond the range observed for the parents.

The means of the progenies obtained by the three methods were significantly different (Table 2). Despite these differences, it was noted that the means of the controls and those of the parents were close to the means of the five best lines derived from each method. This small difference between elite lines (progenies), which in this case included the parents, control cultivars, and developed lines, is consistent with the current situation of breeding programs in Brazil and throughout the world, i.e., the difficulty of finding genotypes that are superior to commercial cultivars. Thus, studies that evaluate the effectiveness of methods for the breeding and selection of segregating populations should be used to assist breeders in decision making.

The findings of the present study are useful, since 7 of the 10 best genotypes had a better mean performance than the cultivar Perola, which originated from the SSD and bulk breeding methods (Table 4). It is noteworthy that Perola is one of the most commonly cultivated cultivars in Brazil. Despite the high yield, it has some drawbacks, e.g., susceptibility to Colletotrichum lindemuthianum, a semi-prostrate plant growth, and low lodging tolerance. The possibility of finding progenies superior to this cultivar indicates that the breeding program can achieve genetic gain when strategies such as breeding method selection and evaluation in different environments are adopted.

Considering the estimated genetic parameters, the bulk and SSD methods proved to be most superior because they combined high variability between progenies and greater stability (with the lowest proportion of interaction). Differences between breeding methods may be related to the effects of natural selection (which occur in the bulk method) and the losses resulting from sampling during the selection of segregating populations for grain yield, which is more pronounced in the SSD method.

According to Ramalho et al. (2001), the bulk method is widely adopted due to its flexibility and the possibility of postponing its completion when resources are limited, until a more appropriate time, without influencing the genetic properties. In addition, over the generations, the population undergoes natural selection, which subjects the plants to competition and may contribute to the maintenance of the best-adapted individuals with the highest seed production. Several studies have demonstrated that natural selection works efficiently in the bulk method, which ensures the highest variability in obtaining progenies in the more advanced generations as well as higher yield stability and higher productivity gain rates per generation (Hamblin, 1977; Gonçalves et al., 2001; Corte et al., 2002). Corte et al. (2002) demonstrated the effect of natural selection during the selection of segregating populations by the bulk method, preserving the most suitable individuals for the environment in which the populations were selected. Thus, breeders have to advance segregating populations in different environments to obtain lines that combine good performance and increased adaptation to the cultivation environments in which they perform well (Mendes et al., 2011; Ramalho et al., 2012). A comparison of the bulk method with the other breeding methods revealed its 
Table 4. Overall mean yield $(\mathrm{kg} / \mathrm{ha})$ of common bean $\mathrm{F}_{8}$ progenies, obtained by three breeding methods and evaluated in 10 environments.

\begin{tabular}{|c|c|c|c|}
\hline Method/progeny identification & Mean yield & Method/progeny identification & Mean yield \\
\hline 1. BRS Estilo & 2617 & 26. Bulk 7 & 2406 \\
\hline 2. CNFC 7812 & 2597 & 27. Bulk D. $F_{2} 8$ & 2404 \\
\hline 3. SSD 14 & 2580 & 28. Bulk D. F 15 & 2402 \\
\hline 4. Bulk 9 & 2578 & 29. Bulk 12 & 2401 \\
\hline 5. SSD 12 & 2568 & 30. Bulk 8 & 2377 \\
\hline 6. SSD 1 & 2559 & 31. SSD 4 & 2370 \\
\hline 7. SSD 6 & 2557 & 32. SSD 5 & 2358 \\
\hline 8. SSD 15 & 2542 & 33. Bulk D. F 12 & 2357 \\
\hline 9. SSD 3 & 2522 & 34. Bulk D. $F_{2} 1$ & 2343 \\
\hline 10. Pérola & 2506 & 35. Bulk D. F 13 & 2331 \\
\hline 11. Bulk D. $F_{2} 3$ & 2497 & 36. SSD 9 & 2319 \\
\hline 12. Bulk D. F 2 & 2495 & 37. Bulk 2 & 2311 \\
\hline 13. SSD 10 & 2494 & 38. Bulk 10 & 2306 \\
\hline 14. Bulk 3 & 2484 & 39. Bulk 1 & 2302 \\
\hline 15. Bulk 5 & 2481 & 40. Bulk 4 & 2301 \\
\hline 16. Bulk D. F 14 & 2479 & 41. SSD 11 & 2295 \\
\hline 17. Bulk D. $F_{2} 7$ & 2478 & 42. Bulk D. $F_{2} 6$ & 2280 \\
\hline 18. CNFC 7829 & 2472 & 43. Bulk 14 & 2235 \\
\hline 19. Bulk D. F 10 & 2469 & 44. Bulk D. $F_{2} 4$ & 2225 \\
\hline 20. SSD 8 & 2450 & 45. SSD 13 & 2209 \\
\hline 21. SSD 7 & 2449 & 46. Bulk D. F $F_{2} 9$ & 2206 \\
\hline 22. Bulk D. F 11 & 2437 & 47. Bulk 6 & 2148 \\
\hline 23. Bulk D. $F_{2} 5$ & 2423 & 48. Bulk 11 & 2137 \\
\hline 24. Bulk 15 & 2410 & 49. Bulk 13 & 2090 \\
\hline 25. SSD 2 & 2409 & - & - \\
\hline Controls means & 2562 & Parents means & 2535 \\
\hline
\end{tabular}

Bulk $=$ D. $F_{2}=$ bulk within $\mathrm{F}_{2}$ families; $\mathrm{SSD}=$ Single-Seed descent.

efficiency, especially when gains in grain yield are obtained, due to natural selection, which ranged from 2.5 to $4.8 \%$ per generation (Gonçalves et al., 2001; Corte et al., 2002), compared to gains from artificial selection (Faria et al., 2013).

The SSD method is not affected by natural selection and permits the rapid development of lines when performed in a greenhouse. This is because for every generation from $\mathrm{F}_{2}$, one seed per plant is sampled, with no allelic loss among progenies, but with high allelic loss within the progeny. Compared to the bulk method, the sampling of segregating population in the SSD method is less intense, which might indicate reduced genetic variability within the progenies (Martin et al., 1978; Fouilloux and Bannerot, 1988; Mehta and Zaveri, 2000). In contrast, the sampling effect is not restricted to the SSD method, and sampling losses have also been reported as a disadvantage of the bulk method. According to Ramalho et al. (2012), taking the effective population size $\left(N_{\mathrm{e}}\right)$ as the reference, in the $\mathrm{F}_{2}$ generation, the $\mathrm{N}_{\mathrm{e}}$ from bulk selection is 0.4 and that of SSD is 0.62 . In $\mathrm{F}_{5}$ the $N_{\mathrm{e}}$ of bulk selection increases to 0.55 and to 16 for SSD. However, it should be emphasized that in bulk selection, a population with a large number of individuals (high $N_{\mathrm{e}}$ ) can be used, reducing the chance of allelic loss per sample. Therefore, at least 2000 plants in $\mathrm{F}_{5}$ for bulk selection (as it is often done) corresponds to an effective size of $1040\left(N_{\mathrm{e}}=\right.$ $0.52 \times 2000)$, which is equivalent to the use of 65 plants in SSD (1040/16).

The comparison of breeding methods for grain yield has revealed the superiority of SSD and bulk methods to generate superior progenies. Raposo et al. (2000) evaluated the genetic potential of segregating populations for grain yield in common bean, conducted by genealogical, bulk, SSD, bulk in $\mathrm{F}_{3}$, and bulk in $\mathrm{F}_{2}$ selection. These authors considered the estimates of genetic and phenotypic parameters, along with the simplicity of implementing 
the methods, and concluded that the SSD and bulk methods were superior in relation to the generation of lines with higher yield potential. The results of the present study indicate that the SSD and bulk methods remain the most effective strategies to generate superior progenies for grain yield, even under the current conditions of main plant breeding programs, where the detectable differences are decreasing.

In conclusion, the lines developed by SSD and bulk selection provided greater genetic variance, higher heritability, mean and selection gain for grain yield than the bulk in $\mathrm{F}_{2}$ method. The SSD and bulk methods enabled the development of the most promising lines and were least affected by the GE interaction.

\section{Conflicts of interest}

The authors declare no conflict of interest.

\section{ACKNOWLEDGMENTS}

The authors thank Universidade Federal de Goiás by the study opportunities and the Coordenação de Aperfeiçoamento de Pessoal de Nível Superior (CAPES) for the postgraduate scholarship of V.A. Pontes Júnior. Research supported by Embrapa Arroz e Feijão. P.G.S. Melo, H.S. Pereira and L.C. Melo were supported with awards for technological development and innovative extension from Conselho Nacional de Desenvolvimento Científico e Tecnológico (CNPq).

\section{REFERENCES}

Brasil (2006). Ministério da Agricultura, Pecuária e Abastecimento. Instrução Normativa n. 25, de 23 de maio de 2006. Anexo I: Requisitos mínimos para determinação do valor de cultivo e uso de feijão (Phaseolus vulgaris) para a inscrição no registro nacional de cultivares - RNC. http:/extranet.agricultura.gov.br/sislegis-consulta/servlet/ VisualizarAnexo?id=11376. Accessed on January 21, 2016.

Carbonell SAM, Azevedo Filho JA, Dias LAS, Garcia AAF, et al. (2004). Common bean cultivars and lines interactions with environments. Sci. Agric. 61: 169-177. http://dx.doi.org/10.1590/S0103-90162004000200008

Chigeza G, Mashingaidze K and Shanahan P (2013). Advanced cycle pedigree breeding in sunflower. I: Genetic variability and testcross hybrid performance for seed yield and other agronomic traits. Euphytica 190: 425-438. http://dx.doi. org/10.1007/s10681-012-0814-x

Corte HR, Ramalho MAP, Gonçalves FMA and Abreu AFB (2002). Natural selection for grain yield in dry bean populations bred by the bulk method. Euphytica 123: 387-393. http://dx.doi.org/10.1023/A:1015065815131

Costa JGC, Rava CA and Zimmermann FJP (2002). Comparação da eficiência de métodos de seleção em gerações segregantes de feijoeiro-comum considerando a resistência à antracnose e o rendimento Cienc. Agrotec. 26: 244-251.

$<$ unknown $>$ Del Peloso M J and Melo LC (2005). Potencial de rendimento da cultura do feijoeiro comum. Santo Antônio de Goiás: Embrapa Arroz e Feijão.</unknown>

Destro D, Bizeti HS, Garcia LA, Fonseca ICB, et al. (2003). Comparison between the SPD and the SPDS methods for segregating generation advancement in soybean. Braz. Arch. Biol. Techn. 46: 545-551. http://dx.doi.org/10.1590/ $\underline{\text { S1516-89132003000400008 }}$

Fahim M, Dhanapala MP, Senadhira D and Lawrence MJ (1998). Quantitative genetics of rice II. A comparison of the efficiency of four breeding methods. Field Crops Res. 55: 257-266. http://dx.doi.org/10.1016/S0378-4290(97)00090-7

Feijão (2015). Dados de conjuntura da produção de feijão e caupi no Brasil: 1985-2012. http://www.cnpaf.embrapa.br/ socioeconomia/index.htm. Accessed on January 15, 2015.

Faria LC, Melo PGS, Pereira HS, Del Peloso MJ, et al. (2013). Genetic progress during 22 years of improvement of carioca-type common bean in Brazil. Field Crops Res. 142: 68-74. http://dx.doi.org/10.1016/j.fcr.2012.11.016

Fouilloux G and Bannerot H (1988). Selection methods in the common bean (Phaseolus vulgaris). In: Genetic resources of Phaseolus beans (Gepts P, eds.). Kluwer, Dordrecht, 503-541.

Genetics and Molecular Research 15 (3): gmr.15038622 
Funada M, Helms TC, Hammond JJ, Hossain K, et al. (2013). Single-seed descent, single-pod, and bulk sampling methods for soybean. Euphytica 192: 217-226. http://dx.doi.org/10.1007/s10681-012-0837-3

Gonçalves FMA, Ramalho MAP and Abreu FB (2001). Natural selection in four common bean traits. Crop Breed. Appl. Biotechnol. 1: 213-220. http://dx.doi.org/10.13082/1984-7033.v01n03a01

Hamblin J (1977). Plant breeding interpretations of the effects of bulk breeding on four populations of beans (Phaseolus vulgaris L.). Euphytica 26: 157-168. http://dx.doi.org/10.1007/BF00032081

Kanbar A, Kondo K and Shashidhar HE (2011). Comparative efficiency of pedigree, modified bulk and single seed descent breeding methods of selection for developing high-yielding lines in rice (Oryza sativa L.) under aerobic condition. Electron. J. Plant Breed. 2: 184-193.

Lalić A, Kovačević J, Novoselović D, Drezner G, et al. (2003). Comparison of pedigree and single seed descent method (SSD) in early generation of barley. Poljoprivreda (Osijek) 9: 33-37.

Martin RJ, Wilcox JR and Laviolette FA (1978). Variability in soybean progenies developed by single seed descent at two plant populations. Crop Sci. 18: 359-362. http://dx.doi.org/10.2135/cropsci1978.0011183X001800030001x

Matos JW, Ramalho MAP and Abreu AFB (2007). Trinta e dois anos do programa de melhoramento genético do feijoeirocomum em Minas Gerais. Cienc. Agrotec. 31: 1749-1754. http://dx.doi.org/10.1590/S1413-70542007000600022

Meena HP and Kumar J (2012). Relative efficiency of different breeding methods for improvement of yield and yield components in chickpea. J. Food Leg. 25: 165-170.

Mehta DR and Zaveri PP (2000). Plant loss during SSD scheme in cowpea. Agric. Sci. Digest 20: 24-26.

Melo LC, Melo PGS, Faria LC, Diaz JLC, et al. (2007). Interação com ambientes e estabilidade de genótipos de feijoeirocomum na Região Centro-Sul do Brasil. Pesq. Agropec. Bras. 42: 715-723. http://dx.doi.org/10.1590/S0100204X2007000500015

Mendes MP, Ramalho MAP and Abreu AFB (2011). Strategies in identifying individuals in a segregant population of common bean and implications of genotype $\mathrm{x}$ environment interaction in the success of selection. Genet. Mol. Res. 11: 872-880. PubMed http://dx.doi.org/10.4238/2012.April.10.3

Moreira SO, Silva MGM, Rodrigues R, Viana AP, et al. (2010). Breeding methods and history of bean cultivars released in CBAB - Crop Breeding and Applied Biotechnology Crop Breed. Appl. Biotechnol. 10: 345-350. http://dx.doi. org/10.1590/S1984-70332010000400009

Miladinović J, Burton JW, Balešević Tubić S, Miladinović D, et al. (2011). Soybean breeding: comparison of the efficiency of different selection methods. Turk. J. Agric. For. 35: 469-480.

Ntanos DA and Roupakias DG (2001). Comparative Efficiency of Two Breeding Methods for Yield and Quality in Rice. Crop Sci. 41: 345-350. http://dx.doi.org/10.2135/cropsci2001.412345x

Pereira HS, Melo LC, Faria LC, Del Peloso MJ, et al. (2009). Adaptabilidade e estabilidade de genótipos de feijoeirocomum com grãos tipo carioca na Região Central do Brasil. Pesq. Agropec. Bras. 44: 29-37. http://dx.doi.org/10.1590/ $\underline{\text { S0100-204X2009000100005 }}$

Pereira HS, Melo LC, Faria LC, Del Peloso MJ, et al. (2010). Indicação de cultivares de feijoeiro-comum baseada na avaliação conjunta de diferentes épocas de semeadura. Pesq. Agropec. Bras. 45: 571-578.

Pereira HS, Almeida VM, Melo LC, Wendland A, et al. (2012). Influência do ambiente em cultivares de feijoeiro-comum em cerrado com baixa altitude. Bragantia 71: 165-172. http://dx.doi.org/10.1590/S0006-87052012005000024

Pontes Júnior VAP, Melo PGS, Pereira HS, Bassinelo PZ, et al. (2015). Genetic potential of common bean progenies selected for crude fiber content obtained through different breeding methods. Genet. Mol. Res. 14: 5763-5774. PubMed http://dx.doi.org/10.4238/2015.May.29.8

Ramalho MAP, Abreu AFB and Santos JB (2001). Melhoramento de espécies autógamas. In: Recursos genéticos e melhoramento - plantas (Nass LL, Valois ACC, Melo IS and Valadares-Inglis MC, eds.). Fundação MT, Rondonópolis.

Ramalho MAP, Santos JB, Abreu AFB and Nunes JAR (2012). Aplicações da genética quantitativa no melhoramento de plantas autógamas. Editora UFLA, Lavras.

Raposo FV, Ramalho MAP and Abreu AFB (2000). Comparação de métodos de condução de populações segregantes de feijoeiro. Pesq. Agropec. Bras. 35: 1991-1997. http://dx.doi.org/10.1590/S0100-204X2000001000010

Ribeiro EH, Pereira MG, Coelho KS and Freitas Júnior SP (2009). Estimativas de parâmetros genéticos e seleção de linhagens endogâmicas recombinantes de feijoeiro comum (Phaseolus vulgaris L.). Rev. Ceres. 56: 580-590.

Silva ACF, Melo PGS, Melo LC, Bassinello PZ, et al. (2013). Eficiência de métodos de melhoramento para teor de fibra e produtividade de grãos em progênies de feijoeiro comum. Bragantia 72: 326-331. http://dx.doi.org/10.1590/ brag.2013.046

Torga PP, Melo PGS, Pereira HS, Faria LC. et al. (2013). Interaction of common beans cultivars of the black group with years, locations and sowing seasons. Euphytica 189: 239-248. http://dx.doi.org/10.1007/s10681-012-0793-y

Vales M, Séguy L, Bouzinac S and Taillebois J (2009). Improvement of cropping systems by integration of rice breeding:

Genetics and Molecular Research 15 (3): gmr.15038622 
a novel genetic improvement strategy. Euphytica 167: 161-164. http://dx.doi.org/10.1007/s10681-008-9819-x

Vello NA and Vencovsky R (1974). Variâncias associadas às estimativas de variâncias genéticas e coeficientes de herdabilidade. Relatório Científico do Instituto Génetica, Piracicaba 8: 238-248.

Vencovsky R and Barriga P (1992). Genética biométrica no fitomelhoramento. Sociedade Brasileira de Genética, Ribeirão Preto.

Vinayan MT and Govindarasu R (2010). Relative efficiency of biparental mating, single capsule descent, selected bulk and random bulk selections in sesame (Sesamum indicum L.). Electron. J. Plant Breed. 1: 666-674.

Genetics and Molecular Research 15 (3): gmr.15038622 